\title{
Radosław Wójtowicz
}

Uniwersytet Ekonomiczny we Wrocławiu

e-mail: radoslaw.wojtowicz@ue.wroc.pl

\section{WDRAŻANIE SYSTEMÓW KLASY \\ ENTERPRISE CONTENT MANAGEMENT \\ JAKO ZLOŻONE PRZEDSIĘWZIECCIE INFORMATYCZNE}

\begin{abstract}
Streszczenie: Głównym celem artykułu jest zaprezentowanie autorskiej ogólnej metodyki wdrażania systemów klasy ECM w organizacji, będącej wynikiem badań literaturowych oraz doświadczeń praktycznych. W pierwszej części artykułu zaprezentowano najważniejsze definicje z opisywanego obszaru. Zasadniczą treść artykułu stanowi część druga, w której zawarty jest syntetyczny opis proponowanej metodyki oraz przykładowy wykaz prac wdrożeniowych.
\end{abstract}

Słowa kluczowe: Enterprise Content Management, zarządzanie treścią przedsiębiorstwa, przedsięwzięcia informatyczne, zarządzanie dokumentami.

DOI: $10.15611 /$ ie.2014.2.19

\section{Wstęp}

Pracownicy organizacji zużywają wiele swojego czasu pracy, by wyszukać potrzebne informacje lub dokumenty, które znajdują się w zasobach danej firmy lub instytucji. Dzięki zastosowaniu nowoczesnych rozwiązań informatycznych i stosowaniu się do reguł przechowywania informacji i dokumentów czas potrzebny do znalezienia wymaganych informacji może ulec znacznemu skróceniu. Organizacje, które wprowadziły tego rodzaju systemy, pracują niewątpliwie wydajniej i są bardziej konkurencyjne. Aby możliwe stało się dyskontowanie bezspornych atutów, jakie posiadają systemy, które stanowią przedmiot dalszych rozważań, konieczne jest stosowanie odpowiedniej metodyki wdrożeniowej, która uwzględni ich specyfikę i pozwoli „bezpiecznie” zrealizować cały projekt.

Podstawowym celem artykułu jest zaprezentowanie ogólnej koncepcji metodyki wdrażania systemu klasy Enterprise Content Management (ECM). Elementy tej metodyki zostały pozytywnie zweryfikowane praktycznie w kilku średnich przedsiębiorstwach przemysłowo-handlowych. Należy również zaznaczyć, że w polskiej literaturze na temat zastosowań systemów IT wciąż brakuje próby systemowego po- 
dejścia do kwestii implementacji systemów klasy ECM. W związku z tym niniejszy artykuł stanowi próbę, przynajmniej częściowego, wypełnienia tej luki.

\section{Podstawowe definicje i rozwój systemów klasy ECM}

Systemy klasy Enterprise Content Management (systemy do zarządzania treścią w przedsiębiorstwie) służą do budowania, porządkowania, zarządzania i przechowywania bazy prac w formie cyfrowej na dowolnych nośnikach i w dowolnym formacie. Zarządzanie treścią stanowi podstawę, czyli infrastrukturę zarządzania wiedzą. Aplikacje na tym rynku obejmują jedną lub więcej spośród następujących funkcji:

- Gromadzenie i zapisywanie dokumentów i treści z innych nośników w zbiory danych za pomocą robotów przeszukujących lub innymi środkami zautomatyzowanymi i/lub ręcznymi oraz przeprowadzanie przechwytywania/wzbogacania metadanych, formatowania, przekształceń i/lub konwersji.

- Porządkowanie i konserwacja informacji, w tym niektóre lub wszystkie z następujących funkcji:

- indeksowanie, katalogowanie i/lub klasyfikacja informacji w systemie zarządzania treścią,

- budowanie katalogów,

- definiowanie przepływów roboczych do śledzenia dokumentów i zmian oraz wysyłanie ostrzeżeń, kiedy potrzebne jest podjęcie czynności,

- ewidencjonowanie, audyt i rejestracja w logach,

- aktualizacja i usuwanie treści,

- wyszukiwanie informacji w systemie zarządzania treścią (mogą być udostępnione wbudowane narzędzia).

- Zapewnienie bezpieczeństwa dokumentów poprzez zarządzanie prawami i zezwoleniami na tworzenie, edycję, umieszczanie i/lub usuwanie materiałów; zarządzanie dostępem użytkowników oraz ochrona własności intelektualnej [Kleu, Micheletti, Roufka 2013].

ECM może dodatkowo wspierać organizację w „poszukiwaniu” istniejącej wiedzy w firmie, np. poprzez tworzenie tzw. map wiedzy - pracownik X w oddziale $Y$ posiada wiedzę dotyczącą tematu $\mathrm{Z}$ itp. Jednak główna funkcja ECM to praca $\mathrm{z}$ informacją i dokumentami w formie elektronicznej. Enterprise Content Management obejmuje cały cykl życia informacji (dokumentu) - od momentu jej zaistnienia w firmie (np. poprzez zeskanowanie rachunku) aż do jej usunięcia.

Organizacja Association for Information and Image Management (AIIM) zdefiniowała system ECM następująco:

Enterprise Content Management są to strategie, metody i narzędzia wykorzystywane do przechwytywania, zarządzania, przechowywania, utrzymywania oraz dostarczania treści i dokumentów związanych z procesami organizacyjnymi. ECM obejmuje zarządzanie informacjami w całym zakresie przedsiębiorstwa, niezależnie 
od tego, czy informacje są w formie dokumentu papierowego, pliku elektronicznego, ciągu danych czy nawet e-maila [AIIM 2014].

AIIM określiła też pięć podstawowych komponentów ECM:

- przechwytywanie (capture),

- zarządzanie (manage),

- przechowywanie (store),

- zachowywanie (preserve),

- dostarczanie (deliver). W ramach tych obszarów można zidentyfikować następujące funkcje szczególowe:

- Skanowanie dokumentów oraz optyczne rozpoznawanie pisma (OCR). System ECM pozwala na skanowanie papierowych dokumentów oraz optyczne rozpoznawanie pisma w celu zamiany zeskanowanych obrazów na tekst. Zeskanowane dokumenty oraz dane tekstowe są wówczas łatwiejsze do odszukania niż papierowe dokumenty, np. w segregatorach.

- Pozyskiwanie treści elektronicznych.

Treści, które są już dostępne w formie elektronicznej, mogą być importowane lub dołączane do systemu ECM. Dzięki temu użytkownicy mogą przetwarzać treści zarówno z systemów informatycznych jak i dokumentów papierowych, wykorzystując ten sam interfejs systemu ECM.

- Indeksowanie oraz wyszukiwanie treści.

Treści zachowywane w systemie ECM są automatycznie indeksowane - przygotowywane do przyszłego wyszukiwania, w tym wyszukiwania pełnotekstowego. Użytkownicy mogą wyszukiwać dokumenty poprzez wprowadzenie ciągu znaków, który będzie wyszukiwany w dowolnej części dokumentu.

- Zarządzanie dokumentami.

Dokumenty zarządzane przez system ECM mogą być edytowane, zapisywane w nowej wersji, blokowane w celu uniknięcia jednoczesnych zmian, przywracane lub porównywane z poprzednimi wersjami. Dla dokumentów Microsoft Office funkcje te są zintegrowane z systemem ECM i dostępne bezpośrednio z aplikacji Word, Excel itp.

- Zarządzanie treściami internetowymi (CMS).

System ECM pozwala również zarządzać treścią umieszczaną na stronach firmowych lub portalach. Procesy, które wykorzystują treści internetowe, mogą wykorzystywać dostępne w systemie ECM funkcjonalności (takie jak kontrola dostępu, moderacja, konfigurowanie przepływu pracy).

- Przepływ pracy, obieg dokumentów oraz zarządzanie procesami biznesowymi (BPM).

Bardzo istotną cechą każdego współczesnego systemu klasy ECM jest zapewnienie mechanizmów zarządzania przepływem pracy (workflow), marszrutami (obiegami) dokumentów oraz procesami biznesowymi. Procesy biznesowe najczęściej mogą być modelowane za pomocą notacji BPMN, EPC i BPEL. Ta pierwsza stała się obecnie standardem, ponieważ (przynajmniej w założeniach) 
miała umożliwiać uruchamianie procesów, a wraz z językiem UML stanowi doskonale uzupełniające się narzędzie do tworzenia specyfikacji systemów informatycznych i procesów biznesowych [Drejewicz 2012]. Po skonfigurowaniu procesów biznesowych system przydziela zadania oraz odpowiednie dokumenty odpowiedzialnym za nie pracownikom lub systemom informatycznym (zadania zautomatyzowane). Każdy proces może być monitorowany (np. jego postęp lub status) oraz analizowany (np. średni czas realizacji, nieefektywne miejsca $\mathrm{w}$ procesie).

Rozwiązania informatyczne klasy ECM ewoluowały bardzo szybko, pojawiały się więc wciąż nowe elementy tych systemów, np. związane z wersjonowaniem dokumentu, kiedy każde jego użycie generuje nowe metadane dotyczące treści. Informacja o tym, jak i kiedy zawartość została wykorzystana, pozwala na stworzenie w systemie nowych opcji filtrowania, ścieżek wyszukiwania, przydzielania, firmowych taksonomii i folksonomii, sieci semantycznych i decyzji odnośnie do reguł zarządzania cyklem życia dokumentu. W procesach decyzyjnych wykorzystuje się obecnie bardzo często pocztę elektroniczną i komunikatory internetowe. Nowoczesny system klasy ECM może zapewnić dostęp do danych związanych z tego rodzaju komunikacją i wykorzystywać je w podejmowaniu decyzji biznesowych.

Rozwój w kierunku zintegrowanych rozwiązań odzwierciedlał wspólny trend w branży oprogramowania: postępującą ewolucję w stronę bardziej kompleksowych rozwiązań. W związku z tym obecnie organizacje mają możliwość wdrożenia jednego elastycznego systemu ECM do zarządzania informacjami we wszystkich działach funkcjonalnych [Enterprise 2014].

\section{Koncepcja wdrażania systemów klasy ECM}

Jak można wywnioskować z pierwszej części artykułu, system ECM obejmuje praktycznie wszystkie procesy w organizacji, których celem jest wspieranie procesów gospodarczych poprzez: zbieranie (wyszukiwanie) istniejących informacji (treści), tworzenie nowych informacji, sortowanie informacji, zarządzanie informacją, dystrybuowanie (rozprowadzanie informacji). W związku z tym konieczne staje się odpowiednie zaplanowanie strategii i metodyki wdrożeniowej.

Planowanie strategii jest $\mathrm{z}$ reguły długoterminowe. Na początku należy zdefiniować nadrzędne (najistotniejsze) cele. Należy pamiętać o tym, że cele muszą być osiągalne dla organizacji. W trakcie planowania konieczne jest także uwzględnienie faktu, że strategia nie może spowalniać aktualnych przemian w przedsiębiorstwie. Głównym celem strategii powinny być zawsze wspieranie i poszukiwanie rozwiązań dla najważniejszych problemów.

Przedsięwzięcie informatyczne, jakim jest wdrożenie systemu klasy ECM, jest niewątpliwie przedsięwzięciem złożonym, wymagającym odpowiedniego zarządzania projektem. W trakcie opracowywania planu zarządzania tego rodzaju projektem wdrożeniowym w organizacji powinno się uwzględnić następujące czynniki: 
- cele i definicje projektu (czynniki sukcesu przedsiębiorstwa, co jest głównym celem),

- analizę wymagań,

- przepisy prawne (odpowiedzialność „zewnętrzna”, np. prawo handlowe, odpowiedzialność „wewnętrzna”, np. ochrona danych, odpowiedzialność za produkty i usługi itp.)

- strategię IT (architektura sprzętu i oprogramowania, łatwość integracji z innymi aplikacjami, dostępność na rynku międzynarodowym, usability).

- możliwości rynkowe i techniczne (obecna oferta na rynku, produkty powielarne vs. rozwiązania dedykowane) [Boehn 2014].

Jak wynika z doświadczeń osób zajmujących się wdrożeniami systemów wspomagających pracę grupową, w przypadku systemów ECM nie sprawdzają się metodyki typu „wielki wybuch” (big-bang), ponieważ wprowadzałyby zbyt duży chaos w funkcjonowaniu przedsiębiorstwa. Przeświadczenie to znalazło odzwierciedlenie w zaproponowanej w tej części opracowania metodyce. Należy dodać, że ze względu na ograniczenia objętościowe $\mathrm{w}$ artykule skupiono się na najważniejszych założeniach metodyki, jej podstawowych fazach i etapach uzupełnionych kilkoma uwagami o charakterze pragmatycznym.

Chcąc umiejscowić proponowaną metodykę $\mathrm{w}$ ramach modelowych metodyk tworzenia oprogramowania, można stwierdzić, że jej założenia są najbliższe metodykom nazwanym prototypowaniem i realizacją przyrostową. Pierwsza z nich polega na stosunkowo szybkim stworzeniu prototypu aplikacji, który podlega testowaniu i weryfikacji przez klienta, a następnie z reguły system jest budowany od podstaw. Druga z nich bazuje na wybraniu pewnego podzbioru funkcji systemu i iteracyjnym procesie ich realizacji. W proponowanej metodyce budowany jest częściowy prototyp aplikacji, który następnie jest rozbudowywany i modyfikowany, aż do osiągnięcia pełnej funkcjonalności. Należy przy tym zauważyć, że w praktyce najczęściej prototypowany będzie system zarządzania dokumentami (DMS), który stanowi podstawę tworzenia i rozbudowy systemu ECM.

Najważniejszą cechą opisywanej metodyki jest całościowe spojrzenie na stosowane strategie zarządcze, procesy gospodarcze, zadania i role pracowników oraz funkcje technologii obecnych w dotychczasowych rozwiązaniach systemowo-organizacyjnych stosowanych w przedsiębiorstwie planującym wdrożenie systemu zarządzania treścią. Dzięki temu podczas projektowania, programowania i wdrażania aplikacji, która ma wspomagać zarządzanie informacjami i dokumentami, można tworzyć rozwiązania najbardziej efektywne, spełniające w możliwie największym stopniu wymagania użytkowników.

Ważną cechą prezentowanej metodyki jest strukturalno-iteracyjne prototypowanie aplikacji, które jest oparte na ściśle zdefiniowanych etapach budowy i implementacji systemu klasy ECM. Po zakończeniu tych etapów osiągnięte cele i korzyści są porównywane z poniesionymi kosztami. Aby określić kolejne iteracje, należy ustalić odpowiednie kryteria, które pozwolą zmierzyć i oszacować wartość każdej itera- 
cji. Takie podejście pozwala również na zastosowanie metody EVA/EVM (Eearned Value Analysis/Earned Value Management), która polega m.in. na mierzeniu i śledzeniu postępu prac za pomocą pojęć związanych z kosztami, czasem i osiągniętymi wynikami, a następnie porównywaniu otrzymanych wartości z ujętym strukturalnie zakresem przedsięwzięcia [Dudycz, Dyczkowski 2006].

W praktyce stosowanie przedstawianej metodyki sprowadza się do podziału projektu tworzenia i wdrażania systemu na trzy fazy, pozwalające opracować aplikację pilotażową, następnie rozszerzoną aplikację pilotażową i wreszcie aplikację finalną (produkcyjną). Główny nacisk w działaniach wdrożeniowo-programistycznych jest położony na opracowanie działającego prototypu aplikacji, który jest poddawany różnego rodzaju testom dotyczącym zarówno wykrywania błędów w oprogramowaniu, jak i rozszerzenia funkcji aplikacji.

Ogólną koncepcję proponowanej metodyki przedstawia rys. 1.

Faza aplikacji pilotażowej zapewnia zarząazanie dostępem do dokumentów, grupowanie dokumentów według określonych zasad i tworzenie hierarchii dokumentów, automatyczne opisywanie dokumentów i nadawanie im unikatowych identyfikatorów, tworzenie nowych dokumentów za pomocą formularzy, wyszukiwanie i przeglądanie dokumentów, archiwizowanie najważniejszych dokumentów.

Faza rozszerzonej aplikacji pilotażowej obejmuje zakres funkcjonalny aplikacji pilotażowej oraz funkcje umożliwiające: sprawną dystrybucję dokumentów i informacji do poszczególnych adresatów, śledzenie drogi dowolnego dokumentu wewnątrz organizacji (kto i kiedy otrzymał dany dokument, kiedy się z nim zapoznał, co z nim zrobił itp.), natychmiastowe sprawdzenie, u kogo znajduje się dany dokument i co się z tym dokumentem dzieje, otrzymywanie raportów dotyczących np. spraw, które nie zostały załatwione w wymaganym terminie, czy czasów realizacji typowych zadań.

Faza aplikacji finalnej zawiera funkcje rozszerzonej aplikacji pilotażowej uzupełnione o: definiowanie obiegu dokumentów zgodnego ze zdefiniowanymi procedurami, automatyczne rejestrowanie zapisów dotyczących marszruty dokumentów, informowanie przez system, jakie czynności mają być wykonane przez pracownika przy realizacji danego etapu procesu gospodarczego, szybkie wyszukanie (zlokalizowanie) określonego dokumentu oraz sprawdzenie, w jakiej fazie procedury znajduje się dany dokument.

W ramach każdej z wymienionych faz można wyróżnić pięć podstawowych etapów, a mianowicie:

1) wprowadzanie innowacji,

2) tworzenie rozwiązań,

3) wdrażanie rozwiązań,

4) transformacja zarządzania,

5) zarządzanie i utrzymanie. 


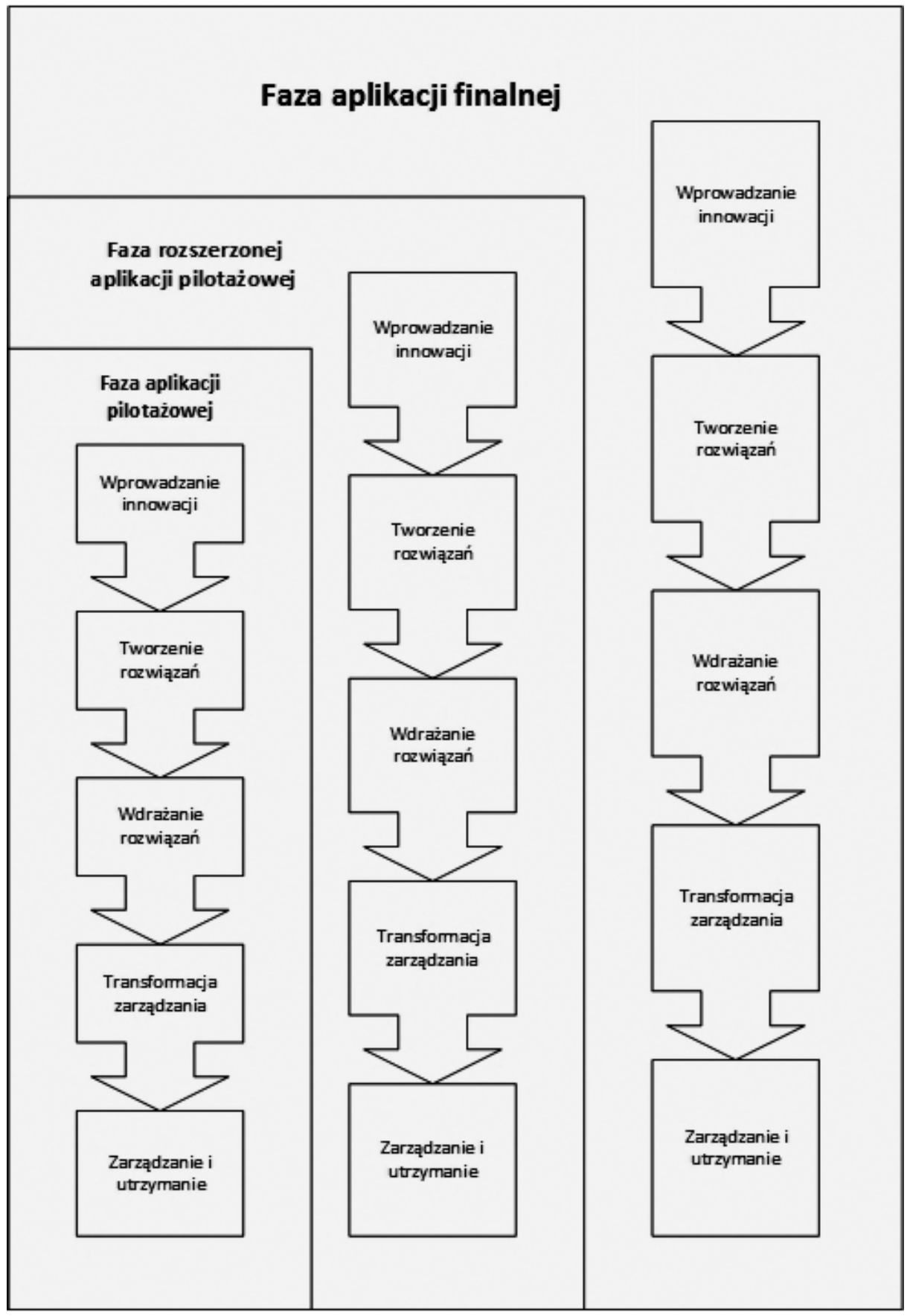

Rys. 1. Ogólna koncepcja proponowanej metodyki wdrożeniowej Źródło: [Wójtowicz 2011]. 
Warto podkreślić, że każdy etap wymaga dużego zaangażowania ze strony klienta. Taki sposób pracy zapewnia najlepsze zrozumienie potrzeb klienta, a w konsekwencji wierne odzwierciedlenie jego oczekiwań w implementowanych systemach.

Wprowadzanie innowacji to przeprojektowanie przebiegu istotnych procesów/ czynności w firmie na podstawie analizy istniejącej struktury i przyjętych przez firmę celów.

Analiza stanu obecnego to przede wszystkim:

1) określenie środowiska, w jakim działa firma,

2) opisanie celów i strategii firmy,

3) przedstawienie schematu infrastruktury technicznej,

4) opracowanie matrycy kompetencji,

5) stworzenie mapy procesów (czynności, przepływy, wymagania, metryki),

6) zidentyfikowanie wykorzystywanych i wymaganych technologii pracy grupowej.

W oparciu o powyższe dane powstaje raport innowacji (proponowanych zmian) z nową koncepcją procesów i ich rozwiązań. Proces innowacji może obejmować całą organizację, wybrane działy lub zespoły robocze.

Tworzenie rozwiązań to transformacja zmian opisanych $w$ raporcie innowacji w prototyp aplikacji, która powstaje jako wynik wspólnej pracy zespołu złożonego z analityków firmy informatycznej (dostawcy) i przyszłych użytkowników (klienta).

Wdrażanie rozwiązań to etap obejmujący czynności i zadania związane z implementacją stworzonych aplikacji:

1) określenie schematu tworzenia aplikacji w iteracyjnym procesie zmian części składowych z wykorzystaniem metody ,przyrostu wartości”,

2) opracowanie standardów aplikacji (interface, komunikacja z otoczeniem),

3) zdefiniowanie architektury systemu,

4) sformułowanie strategii dalszego rozwoju aplikacji i środowiska systemu.

Transformacja zarządzania to etap, w którym formułuje się strategie i podejmuje działania wspierające konieczne zmiany zarówno w zachowaniach, jak i kulturze technicznej pracowników, których dotyczy wdrożenie nowych procesów. Szkolenia, treningi, warsztaty przeprowadzane w tym etapie pozwalają złagodzić naturalną, negatywną reakcję na zmianę stylu i sposobu pracy wynikające z przeprojektowania procesów biznesowych i wprowadzenia nowych technologii.

Zarządzanie i utrzymanie zapewnia końcowy sukces wszystkim przedsięwzięciom podejmowanym podczas realizacji systemu. Etap ten definiuje i narzuca kroki i metody wzajemnej weryfikacji osiągnięcia sukcesu, a także określa zasady komunikacji z klientem zarówno w trakcie projektu, jak i po jego zakończeniu.

Charakterystyczną cechą proponowanej metodyki jest to, że rozwiązanie informatyczne tworzy się w ścisłej współpracy z jego odbiorcą drogą kolejnych, dobrze zdefiniowanych iteracji. Każda z tych iteracji jest samodzielnym, niezależnym rozwiązaniem zwiększającym efektywność działania systemu oraz jego funkcjonal- 
ność. Tego rodzaju metodyka pozwala na bardzo elastyczne balansowanie między wymaganiami wdrażanego systemu a budżetem na przedsięwzięcie.

Osiągnięcie korzyści z wdrożenia systemu klasy ECM jest z pewnością możliwe, jednak trzeba pamiętać o trudnościach i barierach, które należy pokonać podczas wprowadzania takiego rozwiązania w przedsiębiorstwie. Wdrożenie systemu często wymaga więc, jak wspomniano wcześniej, podejścia etapowego, zwiększającego stopniowo zakres funkcjonalny systemu działającego $\mathrm{w}$ danym podmiocie gospodarczym. W praktyce w większości przypadków początkowo zasięg działania systemu obejmuje tylko wybrane informacje i dokumenty.

Na zakończenie rozważań nad metodyką wdrożeniową przedstawimy przykładowy fragment wykazu prac wdrożeniowych, zawierający najważniejsze etapy procesu implementacyjnego. Prace te mogą być wykonywane podczas trwania fazy tworzenia zarówno aplikacji pilotażowej, aplikacji rozszerzonej, jak i aplikacji finalnej (produkcyjnej).

Tabela 1. Przykładowy fragment wykazu prac wdrożeniowych dla systemu klasy ECM

\begin{tabular}{|c|c|c|c|}
\hline Lp. & Opis zadania & $\begin{array}{l}\text { Rola WDRA- } \\
\text { ŻAJĄCEGO }\end{array}$ & Rola KLIENTA \\
\hline 1 & 2 & 3 & 4 \\
\hline I. & \multicolumn{3}{|l|}{ ANALIZA PRZEDWDROŻENIOWA } \\
\hline 1 & $\begin{array}{l}\text { Zebranie materiałów niezbędnych do sporządze- } \\
\text { nia analizy przedwdrożeniowej - wizyta w siedzi- } \\
\text { bie klienta }\end{array}$ & Wykonanie & $\begin{array}{l}\text { Udostępnienie materia- } \\
\text { łów oraz zorganizowanie } \\
\text { spotkań z kluczowymi } \\
\text { użytkownikami }\end{array}$ \\
\hline 2 & $\begin{array}{l}\text { Analiza przedwdrożeniowa i opracowanie koncepcji } \\
\text { wdrożenia w zakresie następujących obszarów: } \\
\text { - obiegu faktur, } \\
\text { - obiegu dokumentów zewnętrznych i wewnętrznych, } \\
\text { - schematów obiegów dokumentów, } \\
\text { - role poszczególnych uczestników w procesie obie- } \\
\text { gu dokumentów, } \\
\text { - teczki w poszczególnych działach, ujednolicenie } \\
\text { wykazu akt, } \\
\text { - zdefiniowanie raportów, } \\
\text { - integracja z systemem zewnętrznym, np. klasy ERP, } \\
\text { - integracja z urządzeniami zewnętrznymi, np. skaner }\end{array}$ & Wykonanie & $\begin{array}{l}\text { Weryfikacja koncepcji } \\
\text { wdrożenia }\end{array}$ \\
\hline II. & \multicolumn{3}{|l|}{ INSTALACJA i KONFIGURACJA } \\
\hline 3 & $\begin{array}{l}\text { Instalacja i konfiguracja systemu na jednym serwe- } \\
\text { rze (jednoserwerowa) }\end{array}$ & Wykonanie & $\begin{array}{l}\text { Udostępnienie zasobów } \\
\text { informatycznych }\end{array}$ \\
\hline 4 & $\begin{array}{l}\text { Dopasowanie systemu do infrastruktury IT klienta. } \\
\text { Instalacja systemu na jednym stanowisku użytkow- } \\
\text { nika końcowego }\end{array}$ & Wykonanie & $\begin{array}{l}\text { Udostępnienie zasobów } \\
\text { informatycznych. } \\
\text { Instalacja na pozostałych } \\
\text { stanowiskach użytkow- } \\
\text { ników końcowych }\end{array}$ \\
\hline
\end{tabular}


Tabela 1, cd.

\begin{tabular}{|c|c|c|c|}
\hline 1 & 2 & 3 & 4 \\
\hline 5 & $\begin{array}{l}\text { Wprowadzenie kont użytkowników oraz struktury } \\
\text { organizacyjnej firmy }\end{array}$ & Wykonanie & $\begin{array}{l}\text { Dostarczenie uporządko- } \\
\text { wanej listy pracowników } \\
\text { (imię, nazwisko, stano- } \\
\text { wisko, dział, e-mail) }\end{array}$ \\
\hline III. & \multicolumn{3}{|l|}{ SZKOLENIA } \\
\hline 6 & $\begin{array}{l}\text { Szkolenie administratora systemu w zakresie podsta- } \\
\text { wowej konfiguracji }\end{array}$ & Szkolenie & $\begin{array}{l}\text { Uczestnictwo w szko- } \\
\text { leniu }\end{array}$ \\
\hline 7 & $\begin{array}{l}\text { Szkolenie sekretariatu w zakresie obsługi korespon- } \\
\text { dencji przychodzącej i wychodzącej }\end{array}$ & Szkolenie & $\begin{array}{l}\text { Uczestnictwo w szko- } \\
\text { leniu }\end{array}$ \\
\hline 8 & $\begin{array}{l}\text { Szkolenie przedstawicieli działów w zakresie obsłu- } \\
\text { gi zamodelowanych procesów }\end{array}$ & Szkolenie & $\begin{array}{l}\text { Uczestnictwo w szko- } \\
\text { leniu }\end{array}$ \\
\hline IV. & \multicolumn{3}{|l|}{ WDROŻENIE WŁAŚCIWE } \\
\hline 9 & Jednorazowy import bazy kontrahentów & Wykonanie & $\begin{array}{l}\text { Dostarczenie bazy kon- } \\
\text { trahentów w pliku Excel. } \\
\text { Dane kontrahentów mu- } \\
\text { szą być uporządkowane } \\
\text { i oczyszczone }\end{array}$ \\
\hline 10 & Wykonanie procedury obiegu faktur & Wykonanie & Konsultacje \\
\hline 11 & $\begin{array}{l}\text { Wykonanie workflow (np. dla zapytań ofertowych, } \\
\text { obsługi zamówienia, urlopów, delegacji itp.) }\end{array}$ & Wykonanie & Konsultacje \\
\hline 12 & $\begin{array}{l}\text { Opracowanie automatycznych importów danych } \\
\text { z systemu ewidencji, w tym np.: } \\
\text { - pobieranie kontrahentów z systemu ERP, } \\
\text { - pobieranie bazy produktów } \\
\text { (ilość i cena), } \\
\text { - pobieranie faktur sprzedażowych i sald }\end{array}$ & Wykonanie & $\begin{array}{l}\text { Zapewnienie dostępu } \\
\text { do systemu ERP oraz } \\
\text { wsparcia partnera wdra- } \\
\text { żającego system ERP }\end{array}$ \\
\hline 13 & $\begin{array}{l}\text { Integracja z systemem ERP, } w \text { tym: } \\
\text { - pobieranie kontrahentów z systemu ERP, } \\
\text { - eksport dokumentów z systemu ECM do syste- } \\
\text { mu ERP }\end{array}$ & Wykonanie & $\begin{array}{l}\text { Zapewnienie dostępu } \\
\text { do systemu ERP oraz } \\
\text { wsparcia partnera wdra- } \\
\text { żającego system ERP }\end{array}$ \\
\hline 14 & Przygotowanie raportów & Wykonanie & $\begin{array}{l}\text { Dostarczenie testowego } \\
\text { zestawu poprawnych da- } \\
\text { nych. Weryfikacja przy- } \\
\text { gotowanych raportów }\end{array}$ \\
\hline V. & \multicolumn{3}{|l|}{ DOKUMENTACJA } \\
\hline 15 & $\begin{array}{l}\text { Opracowanie dokumentacji } \\
\text { wdrożeniowej } \\
\text { dot. obiegu dokumentu }\end{array}$ & Wykonanie & Odbiór dokumentacji \\
\hline 16 & $\begin{array}{l}\text { Opracowanie dokumentacji technicznej dot. integra- } \\
\text { cji z systemem zewnętrznym }\end{array}$ & Wykonanie & Odbiór dokumentacji \\
\hline
\end{tabular}




\begin{tabular}{|c|c|c|c|}
\hline 1 & 2 & 3 & 4 \\
\hline VI. & INNE & & \\
\hline 17 & Zarządzanie projektem & $\begin{array}{l}\text { Koordynacja } \\
\text { prac }\end{array}$ & Koordynacja prac \\
\hline 18 & $\begin{array}{l}\text { Konsultacje zdalne w ramach przekazywanych prac } \\
\text { lub na inne zadane tematy }\end{array}$ & Wykonanie & $\begin{array}{l}\text { Zgłoszenie tematu kon- } \\
\text { sultacji }\end{array}$ \\
\hline 19 & Obsługa techniczna wdrożenia & Wykonanie & Zgłoszenie problemu \\
\hline
\end{tabular}

Źródło: opracowanie własne.

Warto zwrócić uwagę na zadania 12 i 13 - związane z integracją systemu klasy ECM z systemem ERP. Jest to jeden z newralgicznych punktów projektu wdrożeniowego, ponieważ wymaga ścisłej współpracy między dostawcami rozwiązań IT. W polskich firmach najczęściej wypełnianymi dokumentami podlegającymi integracji z innymi systemami są wnioski urlopowe oraz wszelkie rozliczenia związane z delegacjami czy samochodami służbowymi [Marciniak 2010].

W trakcie implementacji systemu klasy ECM konieczne jest często utworzenie nowych, a także modyfikacja istniejących już w organizacji procedur, dlatego proces ten nie może być postrzegany wyłącznie jako instalacja oprogramowania, ale jako zmiana modelu działania przedsiębiorstwa. Aby można było tego dokonać, niezbędna jest integracja i kontrola procesów biznesowych z zasobami informacyjnymi przedsiębiorstwa, wymuszenie zgodności z ustawami, regulacjami, przepisami, normami itd. System zarządzania treścią przedsiębiorstwa nie może być wdrażany na zasadzie „wdrożyć i zapomnieć”. Systemy tej klasy muszą być pod stałym nadzorem, podlegać ciągłym aktualizacjom, dostosowywaniu, modyfikowaniu i rozbudowywaniu [Implementing 2014].

\section{Zakończenie}

Podsumowując przedstawione rozważania, należy podkreślić, że w związku ze specyfiką rozwiązań informatycznych klasy ECM, które wspomagają „rdzeń” obiegu informacyjnego każdej organizacji, konieczne jest wypracowanie takich procedur szczegółowych w trakcie wdrożenia, które będą mogły być stosowane praktycznie przez cały okres życia systemu w organizacji. Od tego bowiem zależy często powodzenie przedsięwzięcia informatycznego jako całości. W trakcie kolejnych prac badawczych dotyczących wdrażania systemów klasy ECM uwaga autora skupi się na aspektach dotyczących pomiaru i oceny skuteczności zaproponowanego podejścia w realizacji rzeczywistych projektów, m.in. z użyciem wspomnianej wcześniej metody wartości uzyskanej (EVA/EVM). 


\section{Literatura}

AIIM, 2014, What is Enterprise Content Management (ECM)?, http://www.aiim.org/What-is-ECM-Enterprise-Content-Management.aspx (25.04.2014).

Boehn M., 2014, Der Weg zum richtigen ECM-System. DMS/ECM-Loesungs-Guide, Isi Medien GmgH, München, s. 11.

Drejewicz S., 2012, Zrozumieć BPMN, Wydawnictwo Helion, Gliwice, s. 11.

Dudycz H., Dyczkowski M., 2006, Efektywność przedsięwzięć informatycznych. Podstawy metodyczne pomiaru i przyktady zastosowań, Wydawnictwo Akademii Ekonomicznej, Wrocław, s. 55-56.

Enterprise, 2014, http://pl.wikipedia.org/wiki/Enterprise_Content_Management (25.04.2014).

Implementing, 2014, http://pl.scribd.com/doc/6538675/Implementing-an-ECMS (25.04.2014).

Kleu T., Micheletti G., Roufka M., 2013, Zarzadzanie treścia w przedsiębiorstwie: Od chaosu do produktywności, White paper IDC, s. 21.

Marciniak M., 2010, Zintegrować wszystko ze wszystkimi, http://www.computerworld.pl/artykuly/363121_2/Zintegrowac.wszystko.ze.wszystkim.html (25.04.2014).

Wójtowicz R., 2011, Zarys metodyki wdrażania system zarzadzania obiegiem dokumentów w przedsiębiorstwie, „Informatyka Ekonomiczna” nr 22, J. Korczak, H. Dudycz (red.), Prace Naukowe Uniwersytetu Ekonomicznego we Wrocławiu nr 212, Wrocław, s. 346-355.

\section{IMPLEMENTATION OF ECM AS A COMPLEX IT PROJECT}

Summary: The main objective of this paper is to present the author's general methodology of the implementation of the ECM systems in the organization resulting from the literature review and practical experience. The first part of the study concentrates on the main definitions. The next and the most important part presents the details of the proposed methodology.

Keywords: Enterprise Content Management, IT-projects, document management. 